\title{
Zika Virus Outbreak - Should assisted reproduction patients avoid pregnancy?
}

\author{
Edson Borges $\mathrm{Jr}_{.}^{1,2}$, Daniela Paes de Almeida Ferreira Braga ${ }^{1,3}$, Bianca Ferrarini Zanetti ${ }^{1}$, Amanda Souza Setti ${ }^{2}$, \\ Rodrigo Rosa Provenza ${ }^{1}$, Assumpto Iaconelli Jr. ${ }^{1}$
}

${ }^{1}$ Fertility - Medical Group, São Paulo, SP - Brazil

2Instituto Sapientiae - Centro de Estudos e Pesquisa em Reprodução Humana Assistida, São Paulo, SP - Brazil 3Disciplina de Urologia, Área de Reprodução Humana, Departamento de Cirurgia, Universidade Federal de São Paulo - UNIFESP

\begin{abstract}
Objective: To discuss the requirement from the National Health Surveillance Agency (ANVISA), for assisted reproduction treatment patients to undergo laboratory tests for ZIKV detection, and if the public health authorities and government leaders' recommendations to women simply avoid pregnancy is prudent.

Methods: This study was performed in a universityaffiliated in vitro fertilization center in Brazil. We present a critical discussion on the risk of microcephaly due to ZIKV infection and the prevalence of other harmful pathogens to vulnerable pregnant women and infants. We assessed, 954 patients undergoing intracytoplasmic sperm injection cycles (ICSI), between April and November of 2016, concerning the results of ZIKV test, according to different regions in Brazil.

Results: Patients undergoing ICSI cycles were split into groups, according to their region of origin: 28 (3.0\%) were from the North, $27(2.8 \%)$ were from the Northeast, $40(4.2 \%)$ were from the Midwest, 830 (87.2\%) were from the Southeast, and $29(3.0 \%)$ were from the South. Concerning the diagnosis, 112 samples had a positive or inconclusive result for ZIKV, by chromatography immunoassay. These samples were re-analyzed by ELISA and no result was positive. All positive results were from the Southeast region and none from the Northeast or Midwest regions, which are considered endemic regions.

Conclusion: ZIKV test before the onset of assisted reproduction treatments does not rule out the risk of the infection during pregnancy. In addition, although ZIKV infection risk is extremely high, the microcephaly risk due to ZIKV is not higher than the risk of miscarriage and birth defects due to other recognized pathogens.
\end{abstract}

Keywords: Zika virus, pregnancy, miscarriage, microcephaly, birth defects.

\section{INTRODUCTION}

Originally discovered in 1947, Zika virus (ZIKV), received special attention since cases of microcephaly were reported following a 2015 outbreak in Brazil (Fauci \& Morens, 2016). For half a century, fewer than 20 human infections were documented (Faye et al., 2014). The first reported outbreak of Zika fever occurred in 2007 on the Western Pacific island of Yap in the Federated States of Micronesia (Duffy et al., 2009); this was followed by a larger epidemic in the French Polynesia, in the South Pacific in 2013 and 2014 (Cao-Lormeau et al., 2014). In 2015, ZIKV emerged in the Americas, and in 2016 ZIKV infection was reported in more than 20 countries or territories in South, Central, and North America (Campos et al., 2015; Zanluca et al., 2015; Enfissi et al., 2016; Hennessey et al., 2016).
Zika virus is predominantly spread via the Aedes species of mosquitos; however, other forms of transmission, including blood transfusion and probable sexual and perinatal transmission, have been reported (Lanciotti et al., 2008; Besnard et al., 2014; Musso et al., 2014; 2015).

Because of its association with congenital defects in the form of primary or congenital microcephaly (Vargas et al., 2001), as well as with paralytic neuropathy symptoms of Guillain-Barré syndrome (Willison et al., 2016), the World Health Organization (WHO) has declared ZIKV to be a Public Health Emergency of International Concern on February 1, 2016 (Heymann et al., 2016).

Much of the concern surrounding ZIKV has focused on the link between infection in pregnancy and fetal microcephaly, and therefore several long-standing complications for both child and the family. In fact, until May of 2016, 7,438 suspected microcephaly cases have been reported in Brazil since ZIKV emerged (1,326 confirmed/4,005 investigated) (Lessler et al., 2016; Victora et al., 2016). Quantifying the risk of microcephaly has been complicated by the uncertainty in the number of ZIKV affected pregnancies, owing to the large fraction of cases that are asymptomatic, a lack of consensus on the definition of microcephaly, and other infectious causes of microcephaly, such as cytomegalovirus and rubella (Lessler et al., 2016).

Although a causal association of ZIKV infection with microcephaly in newborns has not been confirmed, ZIKV introduction in Northeastern Brazil is associated with an increase in congenital malformations in newborns in the same period (Brazilian Health Ministry, 2016).

In a recent statement, the WHO confirms that ZIKV is "spreading explosively" and that the associated level of concern is "extremely high". This was followed by the declaration (February 2, 2016) of public health emergency of international concern around the current outbreak. Moreover, the CDC Emergency Operations Center elevated their response to ZIKV to level 1, the highest level of activation - for only the fourth time in the history of the organization. In addition, public health authorities and government leaders in multiple countries have issued first-ever recommendations for women to simply avoid pregnancy.

Moreover, the Brazilian Ministry of Health described that cases of ZIKV infection have been confirmed by laboratorial tests throughout the whole country (Brazilian Health Ministry, 2015). Additionally, with the symptoms resulting from the infection, the presence of the virus in pregnant women has been associated with cases of microcephaly and deaths of newborns. The presumed correlation between the infection of pregnant women by ZIKV and cases of microcephaly is suggested by the neurotropic character of the virus, which was not found in other organs of the fetus (Mlakar et al., 2016). 
The laboratorial investigation for suspected cases of ZIKV infection includes nonspecific diagnosis and the specific diagnosis, which is based on the in vitro detection of viral RNA, by molecular biology techniques or by the detection of antibodies anti ZIKV, from blood samples.

Therefore, the National Health Surveillance Agency (ANVISA), Collegiate Board Resolution \#72/2016, established that assisted reproduction treatment patients must undergo laboratory tests for the detection of the antibody against ZIKV (IgM), in serum or plasma sample. If the result is reactive or inconclusive, the serological test (IgM) must be repeated, within at least 30 days, or the laboratorial test by molecular biology should be performed according to the assisted reproduction center protocol. For male patients, if the result is positive, tests must be carried out in sperm samples.

If the test result is "Non-reactive", together with the absence of classical and neurological signs and symptoms of ZIKV infection, the controlled ovarian stimulation procedure can be initiated for ovum pickup.

The goal of the present study is to discuss whether the requirement of the National Health Surveillance Agency (ANVISA), to assisted reproduction treatment patients undergo laboratory tests for the detection of ZIKV makes sense, and if the recommendation of public health authorities and government leaders to women simply avoid pregnancy, is a prudent recommendation, based on the prevalence of other potentially harmful agents for pregnant women.

\section{MATERIALS AND METHODS}

This study was performed in a university-affiliated in vitro fertilization center in Brazil, in which the issue concerning the ZIKV infection in pregnant women is a real problem, with drastic consequences for the reproductive population and assisted reproduction centers. Considering the fast spread of ZIKV worldwide, we carry out a critical discussion on the risk of microcephaly due to ZIKV infection, and prevalence of other harmful pathogens to vulnerable pregnant women and infants.

We had 954 intracytoplasmic sperm injection cycles (ICSI), performed between April and November of 2016, evaluated concerning the results of ZIKV test, according to the region of Brazil: North, Northeast, Midwest, Southeast, and South.

The ZIKV test was performed by chromatography immunoassay (Tellmefast, Biocan ${ }^{\odot}$, Coquitlam BC, Canada). The test is a qualitative lateral flow immunoassay for the simultaneous detection and differentiation of IgG and IgM antibodies to ZIKV in human serum. If the test results came positive a second test by enzyme linked immunosorbent assay (ELISA, Eco Diagnóstica, Vale do Sereno, Brazil), was performed. If the ELISA test came positive a PCR would be performed.

\section{RESULTS}

When patients undergoing ZIKV tests, for ICSI cycles, were split into groups according with region of origin we observed that: 28 (3\%) were from the North, 27 $(2.8 \%)$ were from the Northeast, $40(4.2 \%)$ were from the Midwest, $830(87.2 \%)$ were from Southeast, and 29 $(3.0 \%)$ were from the South.

Concerning diagnosis, $112(11.7 \%)$ samples had a positive or inconclusive result from the chromatography immunoassay. These samples were re-analyzed using ELISA and none came back positive.

All positives results were from the Southeast region and none from the Northeast or Midwest regions, which are considered endemic regions (Table 1 ).

Given that other infectious agents may also be potentially harmful for pregnant women, the most prevalent diseases during pregnancy in Brazil, according to epidemiologic data, are summarized in Table 2.

\section{DISCUSSION}

Undoubtedly, ZIKV infection risk deserves special attention, however, the big question is: infection with ZIKV during pregnancy leads to higher risks than other previously known pathogens?".

Pregnant women are exposed to many infectious agents that are potentially harmful. Intrauterine bacterial infection, such as: Chlamydia trachomatis, Neisseria gonorrhea, Treponema pallidum (Syphilis); viral infections, such as: Parvovirus B19, Cytomegalovirus, Varicella zoster (chickenpox), Herpes Simplex Virus; and parasitic infections, such as: Trypanosoma cruzi (Chagas disease), Toxoplasma gondii, and Plasmodium falciparum (Malaria), may represent major risks for pregnant women and fetus.

Investigators studying the 2013-2014 ZIKV outbreak in the French Polynesia estimated that the risk of microcephaly due to ZIKV infection in the first trimester of pregnancy was $0.95 \%$ and recently, the magnitude of the risk of microcephaly in Brazil is estimated to be approximately 0.88\% (Johansson et al., 2016).

In fact, the microcephaly risk due to ZIKV infection is extremely high; however, it is not higher than the risk of other recognized pathogens.

Another important question raised here is about the ZIKV test usefulness for assisted reproduction patients, and weather this may avoid the microcephaly due to ZIKV infection. Our findings demonstrated that the ZIKV infection in patients undergoing assisted reproduction treatments in a center in the Southeast is null, even when performed in patients from endemic regions (Midwest and the Northeast). This shows that during this short period of time, between the test diagnosis and beginning of treatment, the patient may not be infected; however, how to ensure that the infection will not occur in the following months?

Table 1. Distribution of ZIKV testes by Chromatography immunoassay and ELISA in the five Brazilian regions.

\begin{tabular}{|l|c|c|c|c|}
\hline Table 1. Distribution of ZIKV testes by Chromatography immunoassay and ELISA in the five Brazilian regions. & $\begin{array}{c}\text { Chromatography } \\
\text { immunoassay test }\end{array}$ & ELISA test \\
\hline Region & $\mathrm{N}$ & $\%$ & 0 & 0 \\
\hline North & 28 & 3.0 & 0 & 0 \\
\hline Midwest & 27 & 2.8 & 0 & 0 \\
\hline Southeast & 40 & 4.2 & 112 & 0 \\
\hline South & 830 & 87.0 & 0 & 0 \\
\hline Total & 29 & 3.0 & 112 & 0 \\
\hline
\end{tabular}


Table 2. The prevalence of bacterial, viral and parasitic infections during pregnancy.

\begin{tabular}{|l|l|l|l|}
\hline Type & Pathogens & Prevalence & Reference \\
\hline \multirow{5}{*}{ Bacteria } & Chlamydia trachomatis & $2.57 \%$ & (Mylonas, 2012) \\
\cline { 2 - 4 } & Neisseria gonorrhea & $0.7 \%$ to 7\%, & (Rao et al., 2008) \\
\cline { 2 - 4 } & Neisseria gonorrhea (risk group) & $15-35 \%$ & $($ Benzaken et al., 2006) \\
\cline { 2 - 4 } & Treponema pallidum & $0.71 \%$ & $($ Gottlieb et al., 2008) \\
\cline { 2 - 4 } & Herpes Simplex Virus & $2 \%$ & (Brown et al., 2005) \\
\hline \multirow{4}{*}{ Parasites } & Trypanosoma cruzi & $1 \%$ to 40\% & (Martins-Melo et al., 2014) \\
\cline { 2 - 4 } & Toxoplasma gondii & $8 \%-22 \%$ & (Hill \& Dubey, 2016) \\
\cline { 2 - 4 } & Plasmodium falciparum & $2.9 \%$ & (Kourtis et al., 2014) \\
\hline \multirow{5}{*}{} & Parvovirus B19 (endemic period) & $1.5 \%$ & (Valeur-Jensen et al., 1999) \\
\cline { 2 - 4 } & Parvovirus B19 (epidemic period) & $13.0 \%$ & (Preece et al., 1986) \\
\cline { 2 - 4 } & Cytomegalovirus & $0.3 \%$ & (Johansson et al., 2016) \\
\cline { 2 - 3 } & Varicella Zoster & $0.16 \%-0.46 \%$ & \\
\cline { 2 - 3 } & ZikV & $0.88 \%$ & \\
\hline
\end{tabular}

On the other hand, those patients who are already experiencing stress arising from the diagnosis of infertility and the decision to undergo an assisted reproduction treatment, also suffer from the stress of performing the ZIKV test. The instruction to perform the ZIKV associated with the alarming news coming from the media makes these patients even more frightened and stressed.

In conclusion, we believe that ZIKV test before the beginning of assisted reproduction treatments, as established by the National Health Surveillance Agency (ANVISA), Collegiate Board Resolution \#72/2016, does not rule out the risk of such infection during pregnancy. In addition, although ZIKV infection risk is extremely high, especially in endemic regions, the microcephaly risk due to ZIKV is not higher than the risk of miscarriage and birth defects due to other recognized pathogens. Therefore, it is prudent to take precautions to avoid ZIKV as any other infection during pregnancy, and more importantly, pregnant women or those who wish to become pregnant naturally or through assisted reproductive techniques, should stay away from alarming news that takes away the peace of their pregnancies.

\section{CONFLICT OF INTERESTS}

The authors have no conflict of interests to report.

\section{Corresponding author:}

Edson Borges Jr.

Fertility - Medical Group, São Paulo, SP - Brazil

E-mail: edson@fertility.com.br

\section{REFERENCES}

Benzaken AS, Galban EG, Antunes W, Dutra JC, Peeling RW, Mabey D, Salama A. Diagnosis of gonococcal infection in high risk women using a rapid test. Sex Transm Infect. 2006;82:v26-8. PMID: 17118954 DOI: $10.1136 /$ sti.2006.022566

Besnard M, Lastere S, Teissier A, Cao-Lormeau V, Musso D. Evidence of perinatal transmission of Zika virus, French Polynesia, December 2013 and February 2014. Euro Surveill. 2014;19:pii:20751. PMID: 24721538 DOI: $10.2807 / 1560-7917 . E S 2014.19 .13 .20751$
Brazil. Brazilian Health Ministry. Ministério da Saúde divulga boletim epidemiológico. 2015.

Monitoring of cases of dengue. Portal da Saúde; 2015 [cited 2016 Dec 5]. Available at: http://portalsaude.saude. gov.br/index.php/oministerio/principal/secretarias/svs/ zika

Brazil. Brazilian Health Ministry. Chikungunya fever and fever by Zika virus. Epidemiol Week. 2016, 5 [cited 2016 Dec 5]. Available at: http://combateaedes.saude.gov.br/ images/pdf/Informe_Epidemiologico_12_SE_05_2016.pdf

Brown ZA, Gardella C, Wald A, Morrow RA, Corey L. Genital herpes complicating pregnancy. Obstet Gynecol. 2005;106:845-56. PMID: 16199646 DOI: $10.1097 / 01 . A O G .0000180779 .35572 .3 a$

Campos GS, Bandeira AC, Sardi SI. Zika Virus Outbreak, Bahia, Brazil. Emerg Infect Dis. 2015;21:1885-6. PMID: 26401719 DOI: 10.3201 /eid2110.150847

Cao-Lormeau VM, Roche C, Teissier A, Robin E, Berry AL, Mallet HP, Sall AA, Musso D. Zika virus, French polynesia, South pacific, 2013. Emerg Infect Dis. 2014;20:1085-6. PMID: 24856001 DOI: $10.3201 /$ eid2006.140138

Duffy MR, Chen TH, Hancock WT, Powers AM, Kool JL, Lanciotti RS, Pretrick M, Marfel M, Holzbauer S, Dubray C, Guillaumot L, Griggs A, Bel M, Lambert AJ, Laven J, Kosoy O, Panella A, Biggerstaff BJ, Fischer M, Hayes EB. Zika virus outbreak on Yap Island, Federated States of Micronesia. N Engl J Med. 2009;360:2536-43. PMID: 19516034 DOI: $10.1056 /$ NEJMoa0805715

Enfissi A, Codrington J, Roosblad J, Kazanji M, Rousset D. Zika virus genome from the Americas. Lancet. 2016;387:227-8. PMID: 26775124 DOI: 10.1016/S0140-6736(16)00003-9

Fauci AS, Morens DM. Zika Virus in the Americas-Yet Another Arbovirus Threat. N Engl J Med 2016;374:601-4. PMID: 26761185 DOI: 10.1056/NEJMp1600297 
Faye O, Freire CC, Iamarino A, Faye O, de Oliveira JV, Diallo M, Zanotto PM, Sall AA. Molecular evolution of Zika virus during its emergence in the 20(th) century. PLoS Negl Trop Dis. 2014;8:e2636. PMID: 24421913 DOI: $10.1371 /$ journal.pntd.0002636

Gottlieb SL, Pope V, Sternberg MR, McQuillan GM, Beltrami JF, Berman SM, Markowitz LE. Prevalence of syphilis seroreactivity in the United States: data from the National Health and Nutrition Examination Surveys (NHANES) 2001-2004. Sex Transm Dis. 2008;35:507-11. PMID: 18356772 DOI: $10.1097 /$ OLQ.0b013e3181644bae

Helmuth IG, Poulsen A, Suppli $\mathrm{CH}$, Mølbak K. Varicella in Europe-A review of the epidemiology and experience with vaccination. Vaccine. 2015;33:2406-13. PMID: 25839105 DOI: $10.1016 /$ j.vaccine. 2015.03 .055

Hennessey M, Fischer M, Staples JE. Zika Virus Spreads to New Areas - Region of the Americas, May 2015-January 2016. MMWR Morb Mortal Wkly Rep. 2016;65:55-8. PMID: 26820163 DOI: $10.15585 / \mathrm{mmwr} . \mathrm{mm} 6503 \mathrm{e} 1$

Heymann DL, Hodgson A, Sall AA, Freedman DO, Staples JE, Althabe F, Baruah K, Mahmud G, Kandun N, Vasconcelos PF, Bino S, Menon KU. Zika virus and microcephaly: why is this situation a PHEIC? Lancet. 2016;387:719-21. PMID: 26876373 DOI: 10.1016/S0140-6736(16)00320-2

Hill DE, Dubey JP. Toxoplasma gondii as a Parasite in Food: Analysis and Control. Microbiol Spectr 2016;4. PMID: 27726776 DOI: $10.1128 /$ microbiolspec.PFS-0011-2015

Johansson MA, Mier-y-Teran-Romero L, Reefhuis J, Gilboa SM, Hills SL. Zika and the Risk of Microcephaly. N Engl J Med. 2016;375:1-4. PMID: 27222919 DOI: $10.1056 /$ NEJMp1605367

Kourtis AP, Read JS, Jamieson DJ. Pregnancy and infection. N Engl J Med. 2014;370:2211-8. PMID: 24897084 DOI: 10.1056/NEJMra1213566

Lanciotti RS, Kosoy OL, Laven JJ, Velez JO, Lambert AJ, Johnson AJ, Stanfield SM, Duffy MR. Genetic and serologic properties of Zika virus associated with an epidemic, Yap State, Micronesia, 2007. Emerg Infect Dis. 2008;14:12329. PMID: 18680646 DOI: $10.3201 /$ eid1408.080287

Lessler J, Chaisson LH, Kucirka LM, Bi Q, Grantz K, Salje H, Carcelen AC, Ott CT, Sheffield JS, Ferguson NM, Cummings $\mathrm{DA}$, Metcalf $\mathrm{CJ}$, Rodriguez-Barraquer I. Assessing the global threat from Zika virus. Science. 2016;353:aaf8160. PMID: 27417495 DOI: $10.1126 /$ science.aaf8160

Martins-Melo FR, Lima Mda S, Ramos AN Jr, Alencar CH, Heukelbach J. Prevalence of Chagas disease in pregnant women and congenital transmission of Trypanosoma cruzi in Brazil: a systematic review and meta-analysis. Trop Med Int Health. 2014;19:943-57. PMID: 24815954 DOI: 10.1111/tmi. 12328
Mlakar J, Korva $M$, Tul N, Popović $M$, Poljšak-Prijatelj $M$, Mraz J, Kolenc M, Resman Rus $K$, Vesnaver Vipotnik T, Fabjan Vodušek V, Vizjak A, Pižem J, Petrovec M, Avšič Županc T. Zika Virus Associated with Microcephaly. N Engl J Med. 2016;374:951-8. PMID: 26862926 DOI: $10.1056 /$ NEJMoa1600651

Musso D, Nhan T, Robin E, Roche C, Bierlaire D, Zisou K, Shan Yan A, Cao-Lormeau VM, Broult J. Potential for Zika virus transmission through blood transfusion demonstrated during an outbreak in French Polynesia, November 2013 to February 2014. Euro Surveill. 2014;19:pii:20761. PMID: 24739982 DOI: 10.2807/1560-7917.ES2014.19.14.20761

Musso D, Roche C, Robin E, Nhan T, Teissier A, CaoLormeau VM. Potential sexual transmission of Zika virus. Emerg Infect Dis. 2015;21:359-61. PMID: 25625872 DOI: 10.3201/eid2102.141363

Mylonas I. Female genital Chlamydia trachomatis infection: where are we heading? Arch Gynecol Obstet. 2012;285:1271-85. PMID: 22350326 DOI: $10.1007 / \mathrm{s} 00404-012-2240-7$

Preece PM, Tookey P, Ades A, Peckham CS. Congenital cytomegalovirus infection: predisposing maternal factors. J Epidemiol Community Health. 1986;40:205-9. PMID: 3021888 DOI: $10.1136 /$ jech.40.3.205

Rao GG, Bacon L, Evans J, Dejahang Y, Michalczyk P, Donaldson N; Lewisham Chlamydia and Gonoccoccus Screening Programme. Prevalence of Neisseria gonorrhoeae infection in young subjects attending community clinics in South London. Sex Transm Infect. 2008;84:117-21. PMID: 17901085 DOI: $10.1136 /$ sti.2007.026914

Valeur-Jensen AK, Pedersen CB, Westergaard $T$, Jensen IP, Lebech M, Andersen PK, Aaby P, Pedersen BN, Melbye $M$. Risk factors for parvovirus B19 infection in pregnancy. JAMA. 1999;281:1099-105. PMID: 10188660 DOI: 10.1001/jama.281.12.1099

Vargas JE, Allred EN, Leviton A, Holmes LB. Congenital microcephaly: phenotypic features in a consecutive sample of newborn infants. J Pediatr. 2001;139:210-4. PMID: 11487745 DOI: $10.1067 / \mathrm{mpd} .2001 .115314$

Victora CG, Schuler-Faccini L, Matijasevich A, Ribeiro E, Pessoa A, Barros FC. Microcephaly in Brazil: how to interpret reported numbers? Lancet. 2016;387:621-4. PMID: 26864961 DOI: 10.1016/S0140-6736(16)00273-7

Willison $\mathrm{HJ}$, Jacobs BC, van Doorn PA. Guillain-Barre syndrome. Lancet. 2016;388:717-27. PMID: 26948435 DOI: $10.1016 / \mathrm{S} 0140-6736(16) 00339-1$

Zanluca C, Melo VC, Mosimann AL, Santos GI, Santos CN, Luz K. First report of autochthonous transmission of Zika virus in Brazil. Mem Inst Oswaldo Cruz. 2015;110:569-72. PMID: 26061233 DOI: 10.1590/0074-02760150192 